\title{
Indonesian Pasuruan propolis extract does not exert anti- proliferation and pro-apoptotic effect on human colon carcinoma cell line HT-29
}

\author{
Ihda Dian Kusuma ${ }^{1,2 \star}$, Aris Rosidah ${ }^{1,3}$, Eviana Norahmawati ${ }^{2}$, Nurdiana ${ }^{4}$, \\ Agustina Tri Endharti ${ }^{5}$ \\ ${ }^{1}$ Biomedical Magister Program, Faculty of Medicine, Universitas Brawijaya, ${ }^{2}$ Department of Pathology Anatomy, Faculty of \\ Medicine, Universitas Brawijaya, ${ }^{3}$ Department of Pharmacology, Faculty of Medicine, Islamic University of Malang, ${ }^{4}$ Department \\ of Pharmacology, Faculty of Medicine, Universitas Brawijaya, ${ }^{5}$ Department of Parasitology, Faculty of Medicine, Universitas \\ Brawijaya, Indonesia
}

*For correspondence: Email: ihdadiankusuma@ymail.com,dr.ihda@gmail.com

\begin{abstract}
Purpose: To evaluate the anti-cancer activity of Indonesian Pasuruan propolis extract (PPE) against HT-29 human colon carcinoma cell line.

Methods: HT-29 cells were cultured and treated in different concentrations of PPE (50, 100, 200, 400 $\mu \mathrm{g} / \mathrm{mL}$ ) for $24 \mathrm{~h}$. The cells were evaluated by several indicators such as cell proliferation and apoptosis as well as the expression of protein Ki67, p53, cyclin D1, and Bcl-xL.

Results: Administration of PPE inhibited cell proliferation of HT-29 in concentration-dependent manner but the effect was not significant $(p=0.842)$; the results were similar with regard to the expression of Ki67 in HT-29 cells $(p=0.953)$. Administration of $400 \mu \mathrm{g} / \mathrm{mL}$ PPE insignificantly decreased cyclin D1 expression $(p=0.149)$. The concentration of PPE at 50, 100, and $200 \mu \mathrm{g} / \mathrm{mL}$ induced cell apoptosis of HT-29 cells initially, but the level of apoptosis subsequently decreased $(p=0.416)$. Furthermore, the expressions of p53 and Bcl-xL decreased following treatment with PPE at 50, 100 and $200 \mu \mathrm{g} / \mathrm{mL}$ but increased for the PPE $400 \mu \mathrm{g} / \mathrm{mL}$ group $(p=0.000)$.

Conclusion: PPE reduced the expressions of p53, Ki67, cyclin D1, and Bcl-xL insignificantly as it it generally failed inhibit cell proliferation and promote cell apoptosis of HT-29 cells.
\end{abstract}

Keywords: Bcl-xL, Colon cancer, Cyclin D1, Human colon adenocarcinoma cell line HT-29, Proliferation marker Ki67, Tumor protein p53

\begin{abstract}
This is an Open Access article that uses a funding model which does not charge readers or their institutions for access and distributed under the terms of the Creative Commons Attribution License (http://creativecommons.org/licenses/by/4.0) and the Budapest Open Access Initiative (http://www.budapestopenaccessinitiative.org/read), which permit unrestricted use, distribution, and reproduction in any medium, provided the original work is properly credited.
\end{abstract}

Tropical Journal of Pharmaceutical Research is indexed by Science Citation Index (SciSearch), Scopus, International Pharmaceutical Abstract, Chemical Abstracts, Embase, Index Copernicus, EBSCO, African Index Medicus, JournalSeek, Journal Citation Reports/Science Edition, Directory of Open Access Journals (DOAJ), African Journal Online, Bioline International, Open-J-Gate and Pharmacy Abstracts

\section{INTRODUCTION}

Colorectal cancer (CRC) contributed the third highest cancer prevalence in men and the second highest in women worldwide. Despite advanced diagnosis and therapy in recent years, its prevalence is rising, and the 5-years survival rate remains poor. CRC has become a serious healthcare problem in most Asian countries including China, South Korea, Japan, and Singapore, with a 2 to 4 -fold increase in its incidence in 2004-2014 [1]. More efficacious 
approaches are urgently needed for CRC patient.

It has been reported that the inactivity of p53 protein is possibly leads to TP53 gene mutation. p53 mutation occurs in approximately $40-50 \%$ of sporadic CRC. CRC patients with mutant p53 appear to be more chemo-resistant and have poorer prognosis than those with the wild-type [2]. This protein protecting genome from changes as the result of DNA damage by stopping cell cycle and inducing the activation of cell repair mechanisms, as well as cell death [3]. The activation of p53 protein by stress factors will enter into the mitochondria to activate the expression of pro-apoptotic genes, as well as inhibits the expression of anti-apoptotic genes, such as those of the $\mathrm{Bcl}$ family $-2(\mathrm{Bcl}-2, \mathrm{Bcl}-\mathrm{X}$, Bcl-in, Mcl-1) [3].

Propolis is collected by bees from tree exudates primarily resins of leaf bud and other botanical sources. [4]. Propolis has been commonly used as traditional medicine due to its broad spectrum of biological activities, namely anti-cancer, antioxidant, anti-inflammation, and antibiotic activities [4-6]. Previous studies found that Indonesian propolis showed significant anticancer activity when administered in some cancer cell lines beside HT-29 [6-8]. This research aimed to observe the effect of Indonesian Pasuruan propolis extract (PPE) against HT-29 human colon carcinoma cell line by inhibiting the cell cycle and promoting the expression of apoptotic markers including p53, Ki67, cyclin D1 and Bcl-xL.

\section{EXPERIMENTAL}

\section{Propolis and extraction}

Propolis was collected manually from beehives of Trigona sp. located in Pasuruan (East Java, Indonesia). Prior to the extraction, propolis which has been cleaned was crushed, and placed in an opaque and closed container. The sample (100 g) was extracted with $900 \mathrm{~mL}$ of ethanol at room temperature for 14 days. The obtained solution was filtered and re-extracted twice under the same condition, then evaporated to remove ethanol. PPE was dissolved in dimethylsulfoxide (DMSO) and adjusted to a working concentration with culture medium (DMSO concentration was $0.1 \%$ ) and then stored at $4{ }^{\circ} \mathrm{C}$ until used for treatment.

\section{Determination of PPE content}

The content of PPE was analyzed through liquid chromatography-mass spectrometry/mass spectrometry (LC-MS/MS), consisting of a liquid chromatograph (Shimadzu, Japan) connected to Mass Spectrometer QTRAP 3200 (Applied Biosys-tems, USA). Moreover, the chromatographic separation was conducted using RP-C18 Column Inertsil ODS-3 (2.1 x 150 $\mathrm{mm}, 3 \mathrm{~mm}$ ). The elution was conducted by using $0.1 \%$ formic acid as solvent $A$ and methanol as solvent $B$ at $35{ }^{\circ} \mathrm{C}$. Data acquisition was performed using software Analyst 1.5.1 (Applied Biosystems, USA). The specific parameters for the Multiple Reaction Monitoring (MRM) experiment in positive and negative polarity were optimized using as standards caffeic acid phenethyl ester (CAPE), artepillin C, quercetin, apigenin, chrysin, and kaempferol.

\section{Cell line culture}

HT-29 human colon carcinoma cell line was obtained from the American Type Culture Collection (ATCC, Manassas, VA). Cells were cultured in McCoy's 5A culture medium (SigmaAldrich, MO, USA) supplemented with $10 \%$ Fetal Bovine Serum (Gibco, Invitrogen, USA) and 1\% penicillin-streptomycin (Invitrogen, USA). The cells were grown at $37{ }^{\circ} \mathrm{C}$ in a humidified atmosphere of $5 \% \mathrm{CO}_{2}$ and were routinely subcultured using $0.25 \% \quad(w / v)$ trypsin-EDTA solution.

\section{Flow cytometry analysis}

Cells were cultured in 24-well plates in concentration of $1 \times 10^{6}$ cells/well. Cells were treated with 50, 100, 200 and $400 \mu \mathrm{g} / \mathrm{mL}$ PPE for $24 \mathrm{~h}$ after reaching $70-80 \%$ of cell confluence.

Prior to PPE treatment, the cells were labelled with $10 \mu \mathrm{M}$ carboxysuccinimydil ester (CFSE)(Santa cruz, CA, USA) for 30-60 min. After being labelled, the medium was removed and replaced with fresh complete medium and the test compounds (PPE) were added in the desired concentrations and incubated for $24 \mathrm{~h}$. At the end, cells were collected, then washed twice in phospate buffer saline (PBS), and incubated in $5 \mu \mathrm{g} / \mathrm{mL}$ propidium iodide (PI) for $15 \mathrm{~min}$ at $4{ }^{\circ} \mathrm{C}$ in the dark. CFSE and/or PI-positive cells were determined by flow cytometry (FACSCalibur TM; Becton Dickinson).

\section{Apoptosis detection}

The cell mortality rate was determined through flow cytometry using Annexin V-FITC apoptosis detection kit according to the manufacturer's instructions (BD Bioscience, USA). Cells were washed twice in $300 \mu \mathrm{L}$ cell staining buffer (CSB) (Biocare Medical) and centrifuged at $2500 \mathrm{rpm}$ for $3 \mathrm{~min}$ at $4{ }^{\circ} \mathrm{C}$. The pellets were incubated in 
$2.5 \mu \mathrm{L}$ of annexin V-FITC solution (Biolegend, Cat: SC-7195) for $2.5 \mathrm{~min}$ and incubated in $5 \mu \mathrm{L}$ of propidium iodide (PI) solution (Biolegend) for 5 $\mathrm{min}$ at room temperature in the dark. The population of annexin V-positive cells was evaluated by Flow cytometry (FACS Calibur TM; Becton Dickinson).

\section{Immunocytochemistry for p53, Ki67, Cyclin D1 and Bcl-xL expressions}

Cells $\left(1 \times 10^{5}\right.$ cells/well) were grown for $24 \mathrm{~h}$ on glass coverslips. PPE treatment was given at concentrations of $50,100,200$ and $400 \mu \mathrm{g} / \mathrm{mL}$ for $24 \mathrm{~h}$. Briefly, cells were fixed in $100 \%$ methanol and washed twice with PBS. Incubation with monoclonal antibody against Ki67, p53 tumor suppressor protein (Biocare Medical) by 1:100 dilution, Cyclin D1, and Bcl-xL (Santa cruz, CA, USA) by 1:100 dilution were carried out overnight at $4{ }^{\circ} \mathrm{C}$. This step was followed by incubation with FITC-conjugated secondary antibody (Biocare Medical) for $1 \mathrm{~h}$ at room temperature, followed by Streptavidin-HRP, Diaminobenzidine (DAB), and Meyer incubation. The histology slides were assessed blindly by pathologist. The slides were investigated using light microscope with objective 40X. The percentage of positive cells was measured by counting around 200 cells at four microscope fields that were chosen randomly.

\section{Statistical analysis}

The data are expressed as mean \pm SD. Statistical analysis was performed using SPSS 22 PS software by ANOVA or Kruskall Wallis followed by Least Significant Difference (LSD) post hoc test. Significance level was set at $p<$ 0.05 .

\section{RESULTS}

\section{PPE composition}

Propolis samples from tropical zones, such as Indonesia with its vast biodiversity, have become a subject of increasing scientific and economic attention. The association of propolis investigator concerning in its chemical composition from different geographic regions with biological activities lead to the identification of active principles, a fundamental tool to achieve standardization of this bee product [7]. LCMS/MS analysis indicated that the PPE contained chrysin, kaempferol, quercetin, and CAPE. The main peaks in the chromatogram 5 were identified using standard samples (Figure 1).

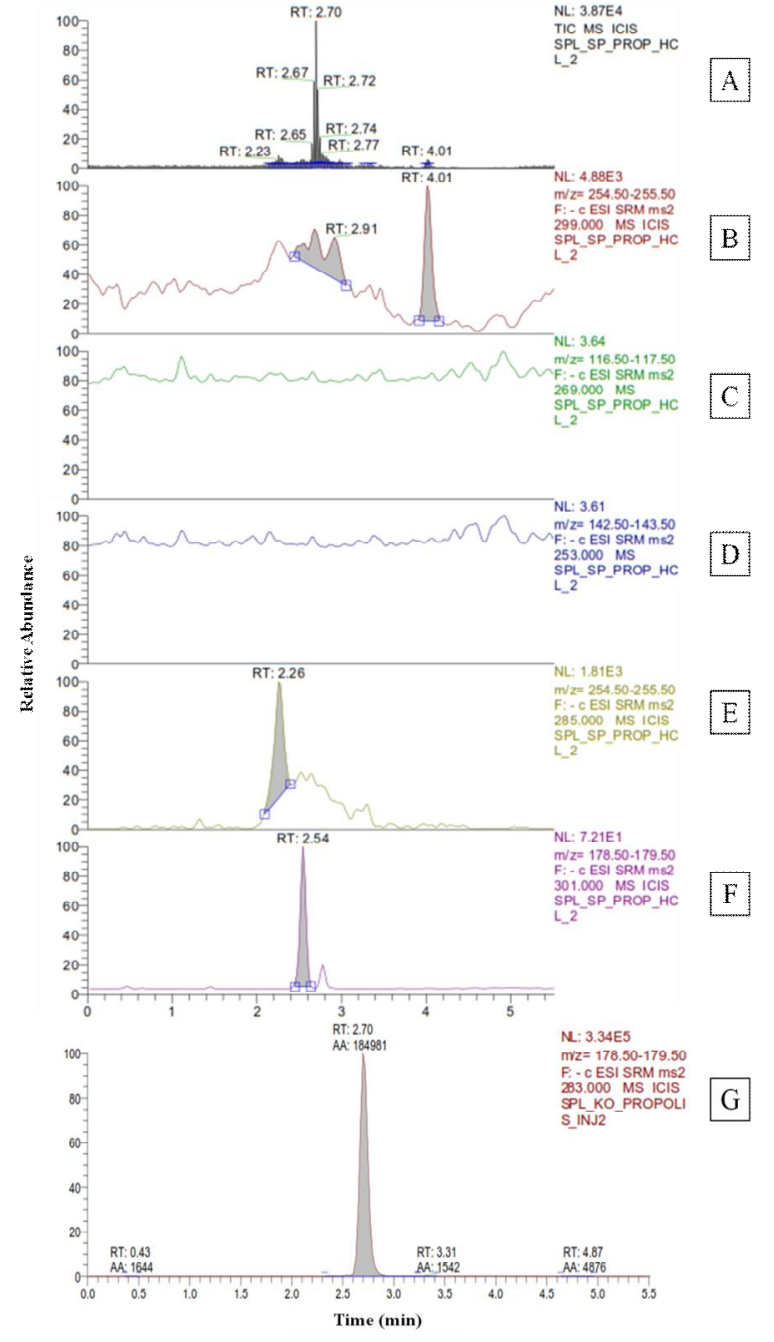

Figure 1: LC-MS/MS chromatograms of PPE used in this study. (A) Total Ion Chromatogram; (B) Artephillin C; (C) Apigenin; (D) Chrysin; (E) Kaempferol; (F) Quercetin; (G) CAPE

\section{PPE downregulates p53 in HT-29 cells}

The immunocytochemistry investigation of HT-29 shows that PPE treatment inhibited the expression of p53 significantly in dosedependent manner $(p=0.000)$ (Figure 2$)$, which is up to $200 \mu \mathrm{g} / \mathrm{mL}$.

\section{PPE slightly reduced HT-29 cell proliferation}

The effect of PPE treatment on cell proliferation was investigated by CFSE marker with flow cytometry. Meanwhile, Ki67 protein expression in HT-29 cells was investigated through immunocytochemistry. It could be seen that PPE treatment inhibited the cell proliferation of HT-29 in concentration dependent manner. However, no obvious changes were observed and were not statistically significant ( $p=0.842$, Figure 3 ). Immunocytochemistry analysis for cell proliferation showed that PPE slightly reduced 

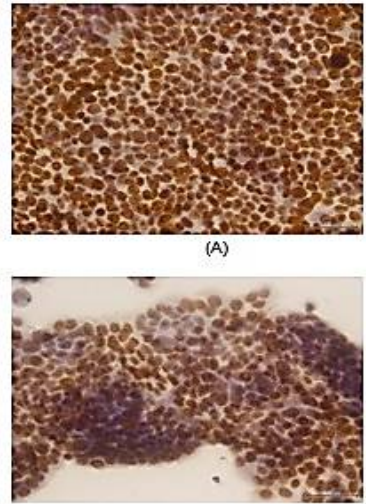

(C)

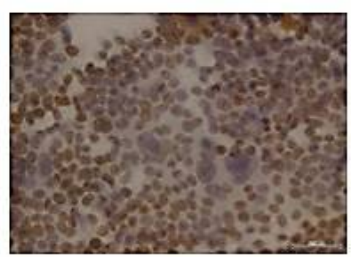

(E)
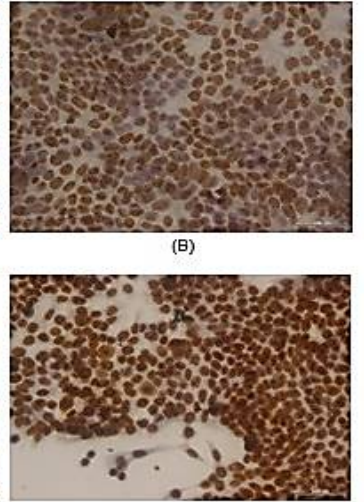

(D)

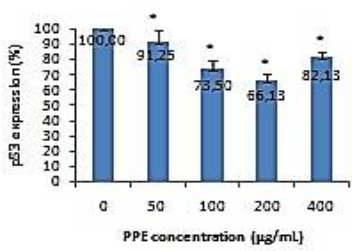

$(\mathrm{P})$
Figure 2: Expression of p53 protein in HT-29 cells after PPE incubation for 24 hours. The cells were incubated in anti BrDu antibody counterstained with hematoxylin and visualized under the light microscope (A) control (untreated group); (B) $50 \mu \mathrm{g} / \mathrm{mL}$; (C) 100 $\mu \mathrm{g} / \mathrm{mL}$; (D) $200 \mu \mathrm{g} / \mathrm{mL}$; and (E) $400 \mu \mathrm{g} / \mathrm{mL}$ PPE; (F) histogram of p53 protein expression. All images were magnified at $400 \mathrm{x}$ and represent independent experiments

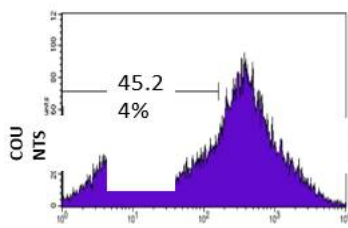

FL1-
CFSE

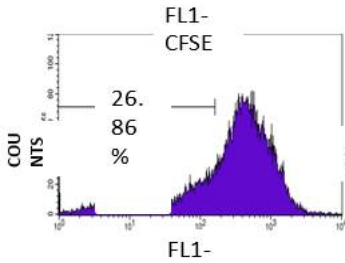

FL1-

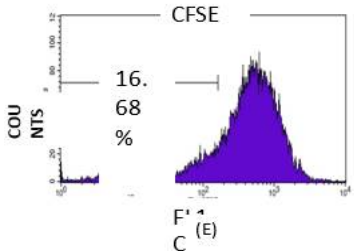

$C^{(E)}$

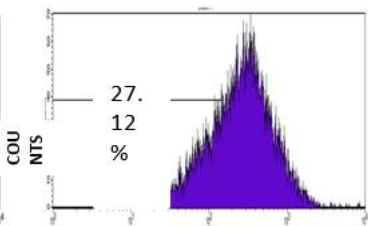
FL1
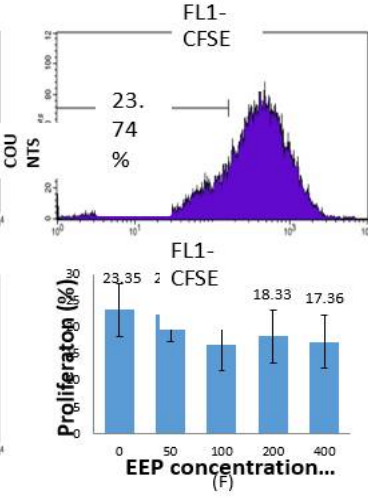

Figure 3: The effect of PPE treatments on cell proliferation in HT-29. (A) control (untreated group); (B-E) HT-29 cells were treated for $24 \mathrm{~h}$ with PPE of $50,100,200$ and $400 \mu \mathrm{g} / \mathrm{mL}$, respectively. $(F)$ the percentages of proliferation. All images were representatives of control (untreated group) and 4 independent experiments

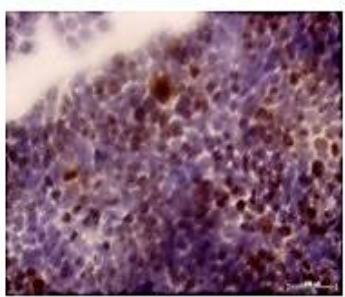

(A)

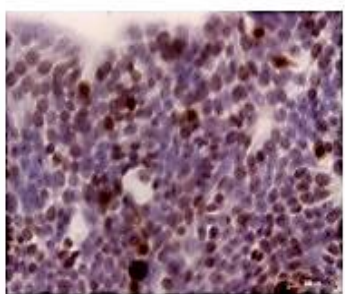

(C)

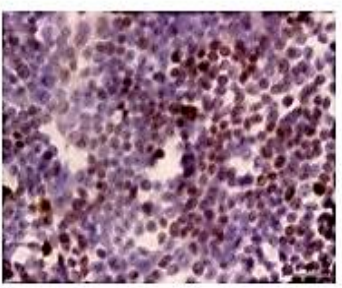

(E)
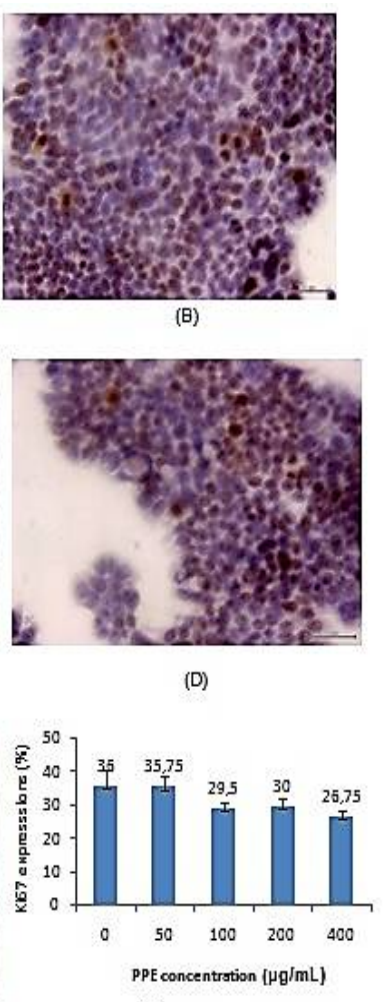

Figure 4: Ki67 expression in HT-29 cells after incubation with PPE for $24 \mathrm{~h}$ in $(\mathrm{A})$ control (untreated group) also (B-E) HT-29 cells that were treated with PPE of 50, 100, 200 and $400 \mu \mathrm{g} / \mathrm{mL}$ for $24 \mathrm{~h}$ respectively and $(F)$ the percentages of Ki67 protein expression

Ki67 protein expression compared to the control but it was not statistically significant $(p=0.953)$ (Figure 4)

\section{Inhibition of Cyclin D1 protein expression by PPE}

HT-29 cells that were treated with PPE in various concentrations $(50-200 \mu \mathrm{g} / \mathrm{mL})$ for $24 \mathrm{~h}$ showed slightly lower level of cyclin D1 expressions than its expression in control group. On the other hand, high concentration of PPE $(400 \mu \mathrm{g} / \mathrm{mL})$ significantly decreased cyclin D1 expression $(p=$ 0.149 , Figure 5).

\section{Apoptosis induction by PPE in a concentration-dependent manner}

The apoptotic effect of PPE in different concentrations, the apoptosis was detected by staining with Annexin $\mathrm{V}$ and PI staining methods. Cells were treated with PPE $(50-200 \mu \mathrm{g} / \mathrm{mL})$ showed slight induction of cell apoptosis, whereas cell treated with $400 \mu \mathrm{g} / \mathrm{mL}$ PPE showed reduction of cell apoptotic more than control group ( $p=0.416$, Figure 6$)$. 


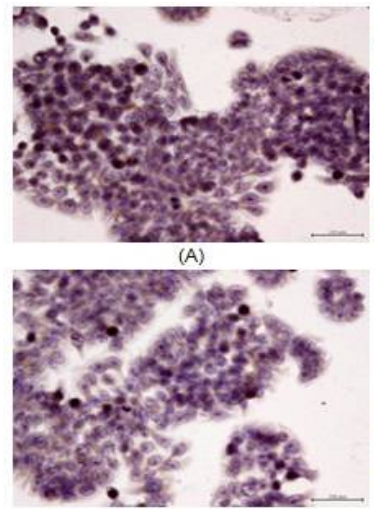

(C)

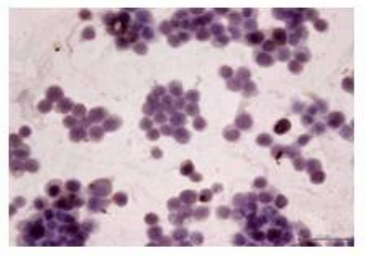

(E)

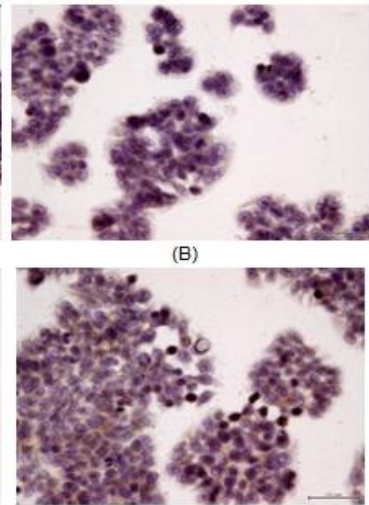

(D)

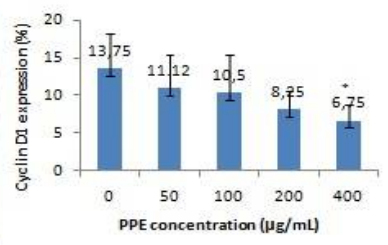

(F)

Figure 5: Effect of PPE on cyclin D1 expression through immunocytochemistry in (A) control (untreated group) and (B-E) HT-29 cells were treated with PPE of 50, 100, 200 and $400 \mu \mathrm{g} / \mathrm{mL}$ for $24 \mathrm{~h}$ respectively with (F) histogram of cyclin D1 protein expression

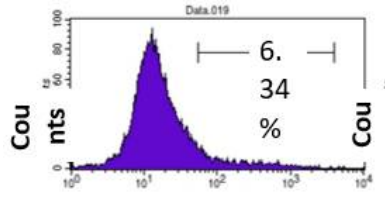
FL1 $_{\text {(A) }}$

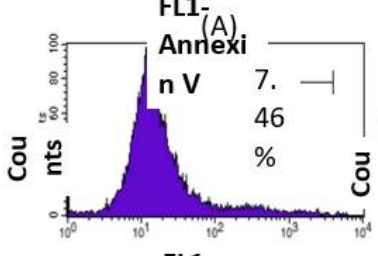

$$
\text { FL1- }
$$

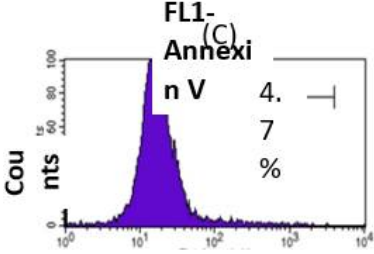

FL1-

Ann'Eexi

n V

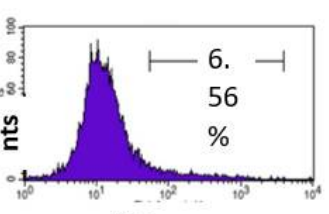

FL1-

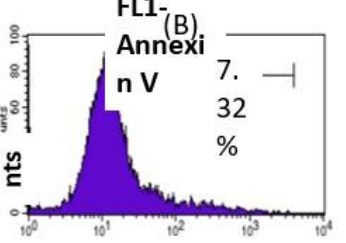

FL1-

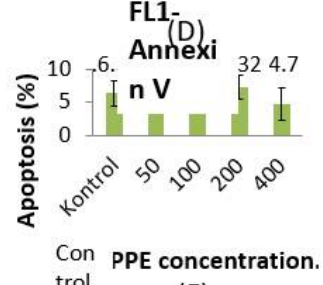

(F)
Figure 6: Cell apoptosis level of HT-29 cells by Annexin $\mathrm{V}$ staining after in $(\mathrm{A})$ control (untreated group) and (B-E) HT-29 cells treated with PPE 50, 100,200 and $400 \mu \mathrm{g} / \mathrm{mL}$ for $24 \mathrm{~h}$ respectively and (F) the apoptotic cells histogram in each group

\section{PPE inhibits Bcl-xL protein expressions}

The determination whether PPE induction of HT29 cell death cells through the regulation of $\mathrm{Bcl}-$ $\mathrm{xL}$ protein and anti-apoptotic proteins following
PPE treatment were analyzed by flow cytometry. In this study, PPE administration downregulated $\mathrm{Bcl}-\mathrm{xL}$ expression significantly. However, its expression was significantly increased when treated with $400 \mu \mathrm{g} / \mathrm{mL}$ PPE $(p=0.000$, Figure 7).

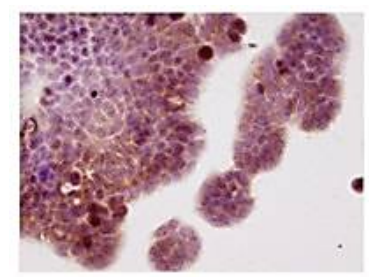

(A)

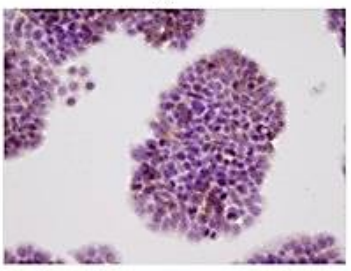

(C)

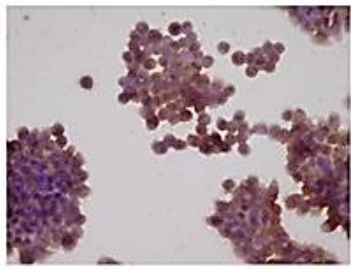

(E)

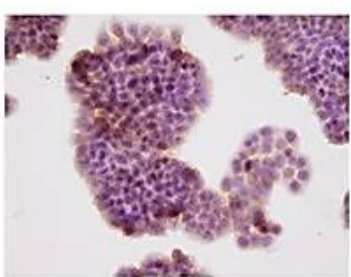

(B)

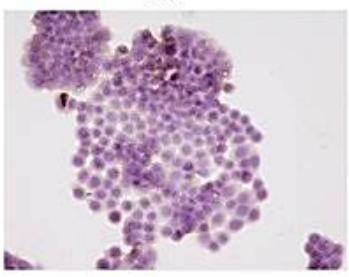

(D)

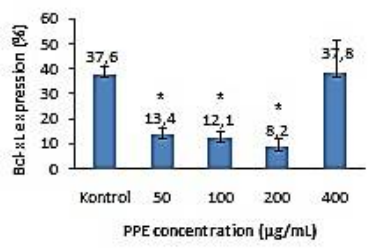

(F)
Figure 7: Immunocytochemistry analysis of $\mathrm{Bcl}-\mathrm{xL}(\mathrm{A})$ control (untreated group) and (B-E) HT-29 cells that were treated PPE 50, 100, 200 and $400 \mu \mathrm{g} / \mathrm{mL}$ respectively for 24 hours; $(\mathrm{F})$ histogram of $\mathrm{Bcl}-\mathrm{xL}$ protein expression in each treatment group

\section{DISCUSSION}

Proliferation plays a pivotal role in the cancer development and progression through the alteration of protein expressions and/or cell cycle related proteins activities [9]. The effect of PPE that indicated its anti-cancer activity by inhibiting proliferation, inducing apoptosis, decreasing expression of p53, Ki67, cyclin D1, and Bcl-xL.

Cyclin D1 is a protein encoded by CCND1 which has been proven to act as an oncogene $[10,11]$. It is included in the family of cyclins that has significant role in cell cycle, particularly in G1 transition to $S$ phase. Cyclin D1 was found overexpressed in more than a third of colorectal cancer cases. In spite of the role of cyclin D has been investigated, the relationship between cyclin D1 expression in colon cancer prognosis has not been clearly revealed yet [12]. The present study found that PPE significantly 
decreased expression of cyclin D1 after treatment with PPE at $400 \mu \mathrm{g} / \mathrm{mL}$.

In the previous experiment, $\mathrm{Li}$ et al showed the effect of the ethanol extract of Brazilian propolis on the metastasis human prostate cancer cells proliferation (DU145 and PC-3) cancer and primary malignant tumor $(\mathrm{RC} 58 \mathrm{~T} / \mathrm{h} / \mathrm{SA \# 4})$. The result showed that propolis botanical origin inhibited the growth of RC58T/h/SA\#4 through the inhibition of cyclin D1 expression [13]. PPE treatment at dose $50-400 \mu \mathrm{g} / \mathrm{mL}$ inhibited the proliferation of HT-29 cell significantly. Although, PPE decreased cyclin D1 expression significantly, but this decline caused to insignificant inhibition of cell proliferation.

For confirmation of cell proliferation activity, we performed immunocytochemical tests of Ki67 expression. The expression of Ki67 nuclear antigen was decreased after PPE administration. However, the result was not statistically significant $(p>0.05)$. This finding is consistent with the result of cell proliferation measurement by flow cytometry. The poor anti-proliferation effect of PPE may indicate that the concentration used should be higher than $400 \mu \mathrm{g} / \mathrm{mL}$, considering that the active ingredient of propolis varies from each site. In addition, regulation of other cell proliferation-related proteins may be required to achieve maximum results. The significant inhibition of cell growth is resulted from the protein expression regulation of cyclin $\mathrm{D} 1, \mathrm{~B} 1$, and cyclin dependent kinase (CDK) as well as p21 [13].

HT-29 cell has a mutant p53. Here we found that PPE significantly decreased the expression of p53. It has also been demonstrated that the PPE derived from the Chinese that was given to MDAMB-231 cells possessing mutant p53. The results show reduction level of mutant p53 in a dosedependent manner [9]. Apoptosis is a wellcharacterized type of programmed cell death and is considered a highly regulated process that allows unwanted or dysfunctional cells to selfdegrade [14]. It is found that PPE at dosage of $50-200 \mu \mathrm{g} / \mathrm{mL}$ induced apoptosis in HT-29 cell in vitro. It has been shown that Indonesian propolis other than PPE also induced cell apoptosis in vitro against other cell lines side HT29 cells $[7,8]$. However, PPE treatment gave insignificant result on inducing apoptosis of HT29 cells was. This is expected due to the lower level of main active component compared to other propolis.

The mechanism of apoptosis seems to be induced by $\mathrm{Bcl}-\mathrm{xL}$ protein regulation as the product of the $\mathrm{Bcl}-2$ gene family that inhibits apoptosis [14]. Therefore, the downregulation of $\mathrm{Bcl}-\mathrm{xL}$ protein leads to Cytochrome $\mathrm{C}$ release by the mitochondria that activates caspase cascade to generate apoptosis [14]. The immunocytochemical study revealed that there was significant decrease in $\mathrm{Bcl}-\mathrm{xL}$ expression in concentration-dependent manner following treatment with PPE at concentrations between 50-200 $\mu \mathrm{g} / \mathrm{mL}$. Our findings suggest that PPE may promote HT-29 cells to apoptosis through $\mathrm{Bcl}-\mathrm{xL}$ down-regulation. However, it did not cause significant increase in apoptosis which suggests that HT-29 cells apoptosis occurs in independent Bcl-xL mechanism.

Interestingly, higher concentration of PPE at 400 $\mu \mathrm{g} / \mathrm{mL}$ increased expression of $\mathrm{Bcl}-\mathrm{xL}$ protein and decreased apoptosis level. The previous studies explained that propolis has antioxidant effects [13]. PPE may provide antioxidant effects at lower doses and mediate ROS induction leading to cell damage and cell death. It has been previously documented that other natural component, such as curcumin which is known to possess strong antioxidant activity, mediate ROS induction and cause myocardial damage [15]. Another study showed that administration of high doses of propolis can cause cell death due to necrosis [16].

According to the result of p53 expression conducted by immunocytochemistry, decreasing expression of p53 did not significantly affect the reduction in cell proliferation and enhancement the cell apoptosis. This phenomenon appeared due to the ability of PPE to reduce the expression of mutant p53 without enhances the function of wild type p53 that allows cell proliferation. When mutant p35 was silenced, it would reduce growth of cellular colony in human cancer cells which was because of the induction of apoptosis [16].

\section{CONCLUSION}

PPE reduced the expression of p53, Ki67, cyclin $\mathrm{D} 1$, and $\mathrm{Bcl}-\mathrm{xL}$ but the decline was not strong enough to inhibit proliferation and promote strong apoptosis signal towards HT-29 human colon carcinoma cell line.

\section{DECLARATIONS}

\section{Acknowledgement}

The authors would like to thank the Medical Faculty of Brawijaya University for BPP funding, and Kembang Joyo Honey Bee Farm for kindly providing the propolis used in the study. 


\section{Conflict of interests}

No conflicts of interest is associated with this work.

\section{Contributions of authors}

We declare that this work was done by the authors (named in this article and all liabilities pertainig to claims relating to the content of this article will be borne by the authors. IDK and AR: research design, data collection, analysis, data interpretation, and writing the manuscript. ND and EN: data analysis and interpretation. ATE: data analysis, data interpretation, and manuscript revision. Therefore, all authors have participated data design, literature study, and final manuscript approval.

\section{REFERENCES}

1. Kustiawan PM, Puthong S, Arung ET, Chanchao C. In vitro cytotoxicity of Indonesian stingless bee products against human cancer cell lines. Asian Pac J Trop Biomed 2013; 4: 549-556.

2. Nowsheen S, Yang ES. The intersection between DNA damage response and cell death pathways. Exp Oncol 2012; 34: 243-254.

3. Wawryk-Gawda, E., Chylińska-Wrzos, P., Lis-Sochocka, M. et al. Protoplasma (2014) 251: 525 . doi. 10.1007/s00709-013-0548-1.

4. Choudhari MK, Haghniaz R, Rajwade JM, Paknikar KM. Anticancer activity of Indian stingless bee propolis: an in vitro study. Evid Based Complementary Altern Med 2013; 928280: 1-10.

5. Sabir A. Aktivitas antibakteri flavonoid propolis Trigona sp terhadap bakteri Streptococcus mutans (in vitro). Maj Ked Gigi (Dent J) 2005; 38: 135-141.

6. Szliszka E, Czuba ZP, Domino M, Mazur B, Zydowicz G, $K \mathrm{Kol} W$. Ethanolic extract of propolis (PPE) enhances the apoptosis- inducing potential of trail in cancer cells. Molecules 2009; 14: 738-754.
7. Hadiyah ZK, Widyarti S, Widodo MA. Local Propolis extract has cytotoxic and antiproliferative effect on hela cells. Jurnal Kedokteran Brawijaya. 2010; 25: 17-21.

8. Syamsudin, Wiryowidagdo S, Simanjuntak $P$, Heffen WL. Chemical composition of propolis from different regions in Java and their cytotoxic activity. Am J Biochem Biotechnol 2009; 5: 180-183.

9. Feitelson MA, Arzumayan A, Kulathinal RJ, Blain SW, Holcombe RF, Mahajna J, Marino M, Martinez-Chantar $M L$, Nawroth R, Sachez-Garcia l, et al. Sustained proliferation in cancer: mechanisms and novel therapeutic targets. Semin Cancer Biol 2015; 35: 25-54.

10. Xuan $H$, Li Z, Yan $H$, Sang $Q$, Wang $K$, He $Q$, Wang $Y$, Hu F. Antitumor activity of chinese propolis in human breast cancer MCF-7 and MDA-MB-231 cells. Evid Based Complementary Altern Med 2014; 280120: 1-11.

11. Mayo C, Mayol X. Cycling D1 negatively regulates the expression of differentiation genes in HT-29 M6 mucussecreting colon cancer cells. Cancer Lett 2009; 281 : 183-187.

12. Peurala E, Koivunen $P$, Haapasaari K-M, Bloigu $R$, Jukkola-Vuorinen $A$. The prognistic significance and value of cyclin D1, CDK4 and p16 in human breast cancer. Breast Cancer Res 2013; 15: 1.

13. Li H, Kapur A, Yang JX, Srivastava S, McLeod DG, Paredes-Guzman JF, Daugsch A, Park YK, Rhim JS. Antiproliferative on human prostate cancer cells by ethanolic extract of Brazilian propolis and its botanical origin. Int J Oncol 2007; 31: 601-606.

14. Choudhury JD, Kumar S, Mayank V, Mehta J, Bardalai D. $A$ review on apoptosis and it's different pathway. Int $J$ Biol Pharm Res 2012; 3: 848-861.

15. Tanwar V, Sachdeva J, Kishore K, Mittal R, Nag TC, Ray $R$, Kumari S, Arya DS. Dose-dependent actions of curcumin in experimentally induced myocardial necrosis: a biochemical, histopathological, and electron microscopic evidence. Cell Biochem Func 2010; 28: 7482.

16. Li XL, Zhou J, Chen ZR, Chng WJ. p53 mutations in colorectal cancer-molecular pathogenesis and pharmacological reactivation. World $J$ Gastroenterol 2015; 21: 84-93. 